\title{
Insulin-like peptide receptor mediated signaling pathways orchestrate regulation of energy homeostasis in the Pacific oyster, Crassostrea gigas
}

Yongjing Li ${ }^{\mathrm{a}}$, Huiru Fu ${ }^{\mathrm{a}}$, Fuqiang Zhang ${ }^{\mathrm{a}}$, Liting Ren ${ }^{\mathrm{a}}$, Jing Tian ${ }^{\mathrm{a}}$, Qi Li ${ }^{\mathrm{a}, \mathrm{b}}$, Shikai Liu ${ }^{\mathrm{a}, \mathrm{b}, *}$

${ }^{a}$ Key Laboratory of Mariculture (Ocean University of China), Ministry of Education, and College of Fisheries, Ocean University of China, Qingdao 266003, China

${ }^{b}$ Laboratory for Marine Fisheries Science and Food Production Processes, Qingdao

National Laboratory for Marine Science and Technology, Qingdao 266237, China

* Corresponding author at: Key Laboratory of Mariculture (Ocean University of China),

Ministry of Education, and College of Fisheries, Ocean University of China

E-mail address: liushk@ouc.edu.cn (S.L.)

Telephone: +86-0532-82032595 
bioRxiv preprint doi: https://doi.org/10.1101/2021.02.25.432956; this version posted February 27, 2021. The copyright holder for this

\section{Research Highlights:}

1. ILPR, IRS, IGFBPRP, and IGFALS genes were characterized in the C. gigas.

2. Major genes of IIS signaling pathway were highly expressed in fast-growing $C$. gigas.

3. IIS and downstream pathways participates in energy homeostasis of oysters.

4. ILPR mediated signaling pathways orchestrate growth regulation in oysters. 


\begin{abstract}
The involvement of insulin/insulin-like growth factor (IIS) signaling pathway in growth regulation of marine invertebrates remains largely unexplored. In this study, we used a fastgrowing Pacific oyster (Crassostrea gigas) variety "Haida No.1" as material to unravel the role of IIS system in growth regulation in oysters. Systematic bioinformatics analyses allowed to identify major components of IIS signaling pathway and insulin-like peptide receptor (ILPR) mediated signaling pathways, including PI3K-AKT, RAS-MAPK, and TOR, in C. gigas. Expression levels of the major genes in IIS and its downstream signaling pathways were significantly higher in "Haida No.1" than wild oysters, suggesting their involvement in growth regulation of $C$. gigas. Expression profiles of IIS and its downstream signaling pathway genes were significantly altered by nutrient abundance and culture temperature. These results suggested that IIS signaling pathway coupled with the ILPR mediated signaling pathways orchestrated energy homeostasis to regulate growth in the Pacific oyster.
\end{abstract}

Key words: Crassostrea gigas, IIS, nutrient abundance, temperature, energy metabolism 


\section{Introduction}

Nutrient abundance is one of the most important environmental factors that are critical to growth and reproduction of all organisms. Nutrient sensing and energy metabolism are coordinated by networks of signaling cascades such as insulin/insulin-like growth factor signaling (IIS), target of rapamycin (TOR), and adenosine monophosphate-activated protein kinase (AMPK) signaling pathways [1]. The IIS and AMPK signaling pathways are two critical coordinators of energy homeostasis and metabolic processes across diverse vertebrate and invertebrate species. The TOR signaling pathway integrates various environmental factors and the signal transducing from the IIS and AMPK pathways to direct the cell growth $[1,2]$.

As one of the most important nutrient sensors, the mechanism of IIS pathway in growth regulation of vertebrates has been well studied. The IIS signaling pathway, including insulin/ insulin-like growth factors (IGFs), insulin/IGF receptor (INSR, ILPR, IGFR), insulin receptor substrate (IRS), insulin-like growth factor-binding proteins (IGFBPs), and insulin-like growth factor-binding protein complex acid labile subunits (IGFALSs), regulates multiple cellular processes, including cell growth and proliferation, energy metabolism, hormone secretion, and glucose homeostasis [3-5]. In vertebrates, the insulin acutely alters in response to the nutrient abundance and other circulating factors to regulate the nutrient uptake and storage activity of organisms [6]. The IGFs are regulated by the growth hormone $(\mathrm{GH})$ which is secreted by neuroendocrine cells of the anterior pituitary gland and function to regulate the growth of organisms $[7,8]$. The levels of IGFs in serum are strictly controlled by the ternary complex "IGF-IGFBP-ALS" [9]. Binding of insulin or IGFs to the tyrosine kinase receptor (INSR, IGFR) leads to activation of receptor and phosphorylation of cellular receptor substrate (IRS) which 
cooperate to trigger the PI3K-AKT and RAS-MAPK pathways to regulate the cell proliferation, glycogen metabolism and protein synthesis $[4,10]$.

Only insulin-like peptide but no growth hormone has been identified in various invertebrates [11-13]. The insulin-like peptides were produced from brain or small clusters of neuroendocrine cells, and involved in the neuroendocrine activity in several insects and gastropod mollusks [14-18]. The insulin-like peptide receptors and various members of IGFBP in invertebrates, which share similar structure and function with their counterparts in vertebrates, have also been identified [19-27]. Furthermore, genes involved in PI3K-AKT and RAS-MAPK signaling pathways, such as $P I 3 K, A K T, P T E N$, and $R A S$ were also identified in invertebrates [28-30]. Levels of expression or phosphorylation of key components of these pathways has been associated with growth difference [29, 31-35]. A recent study in pearl oyster reported that the insulin-like peptide recombinant protein induced the expressions of ILPR and the major genes of PI3K-AKT and RAS-MAPK pathways, suggesting a functional IIS signaling cascade mediated by ILPR [36]. Therefore, systemic characterization of IIS signaling and its downstream pathways that are involved in growth would be essential for unravelling molecular mechanisms of growth regulation in invertebrates such as mollusks.

The Pacific oyster (Crassostrea gigas) is one of the most widely cultured marine mollusks, which has been introduced from Asia to many other countries around the world [37]. A selection breeding program of the C. gigas in China performed for over ten years have produced a fast-growing variety named as "Haida No.1", which exhibits significant growth advantages over wild oysters $[38,39]$. The fast-growing variety provides an ideal research system for growth studies in oyster. In a previous work, we identified four insulin-like peptide genes in $C$. 
gigas, and showed that expression levels of ILPs were significantly higher in fast-growing "Haida No.1" than wild oysters [40]. Environmental factors such as nutrient abundance and ambient temperature had significant effects on expression of ILP genes and growth of oysters. To further understand the roles of IIS signaling pathway in growth regulation of oysters, in this work, we performed an extensive multi-omics data mining to identify key components of IIS, PI3K-AKT and RAS-MAPK signaling pathways in C. gigas. Expression profiles of major genes of the IIS and ILPR mediated signaling pathways were determined in "Haida No.1" and wild oysters. Fasting/re-feeding and low temperature culture experiments were performed to further understand how the IIS signaling pathway was altered by nutrient level and temperature to affect growth of $C$. gigas. This work provided a systemic characterization of IIS and ILPR mediated signaling pathways involved in growth of $C$. gigas, which would provide valuable information toward understanding of molecular basis of growth regulation in oysters and other invertebrates.

\section{Materials and methods}

\subsection{Sequence analysis}

The amino acid sequences of IIS signaling pathway genes, including ILPR, IRS, IGFBP and IGFALS, from Homo sapiens, Gallus gallus, Xenopus laevis, Anolis carolinensis, Danio rerio, Limulus polyphemus, Musca domestica, Tetranychus urticae, Aplysia californica, Mizuhopecten yessoensis, Octopus bimaculoid, Pomacea canaliculata, Crassostrea virginica and Crassostrea gigas were retrieved from the NCBI database. The detailed information of these sequences was provided in Supplementary Table 1. The sequences were aligned using 
ClustalW2 (http://www.ebi.ac.uk/Tools/msa/clustalw2/), and the phylogenetic trees were constructed using neighbor-joining (NJ) approach in MEGA7 [41]. The reliability of topological structure was tested using 1000 bootstrap replications.

\subsection{Real-time PCR and statistical analysis}

All the primers used for real-time PCR were designed by Primer Express software (Applied Biosystems, USA) and provided in Supplementary Table 2. The 2-fold dilutions of cDNA isolated from adductor muscle and the internal control gene elongation factor $1 \alpha($ EF $1 \alpha)$ were used to assess primer efficiency and the primer sets with an efficiency of $90-110 \%$ were used for real-time PCR analysis. The real-time PCR reactions were carried out in a LightCycler 480 machine (Roche, Switzerland) in a $20 \mu \mathrm{L}$ system with a mixture of $10 \mu \mathrm{L} 2 \times$ SYBR Premix ExTaq (Qiagen, Germany), $2.0 \mu \mathrm{L}$ diluted cDNA or double distilled water as a negative control, $6 \mu \mathrm{L}$ PCR-grade water, and $1.0 \mu \mathrm{L}$ each primer $(10 \mu \mathrm{M})$. The PCR reactions were initiated by denaturation at $95^{\circ} \mathrm{C}$ for $3 \mathrm{~min}$, followed by 40 amplification cycles at $95^{\circ} \mathrm{C}$ for $15 \mathrm{~s}$ and $60{ }^{\circ} \mathrm{C}$ for $30 \mathrm{~s}$. Dissociation protocols were used to measure melting curves. The relative expression level (RNA abundance) was calculated by dividing the copy number of the target gene by that of the internal control gene. Data were expressed as the mean \pm SD. Significant differences $(P$ $<0.05$ ) were determined using the one-way ANOVA and Student's $t$-test for single or multiple comparisons, respectively.

2.3. Expression profiles of the major genes in IIS, PI3K-AKT and RAS-MAPK signaling pathways 
Expression profiles of the major genes in IIS, PI3K-AKT and RAS-MAPK signaling pathways, including ILPR, IRS, IGFBPRP, IGFALS, PI3K, PDK, AKT, RAS, MEK, ERK, PTEN, $T O R, F o x O, G S K 3 \beta$, and $S 6 K$, were determined in the adductor muscle of "Haida No.1" and wild oysters. Total RNA was extracted using Trizol Reagent (Invitrogen) and reversely transcribed into cDNA according to the PrimeScript ${ }^{\mathrm{TM}}$ RT reagent Kit with gDNA Eraser (Perfect Real Time) (TaKaRa, Japan) manufacturer's instructions. Real-time PCR was carried out as described above.

\subsection{Fasting and re-feeding culture experiment}

Ninety 8-mounth-old $C$. gigas were randomly divided into three groups and used for fasting and re-feeding experiment. Six oysters collected before the experiment were used as control (as indicated by C), the other oysters were starved for 14 days and then refed with frozen Chlorella ad libitum for 36 hours. Samples were collected on day 1, 3, 5, 7 and 14 (as indicated by F1d, F3d, F5d, F7d and F14d, respectively) during fasting process, and collected at 1, 3, 6, 12, 24 and 36 hours (as indicated by R1h, R3h, R6h, R12h, R24h, R36h, respectively) after re-feeding with six oysters at each time point. Various tissues including the labial palp, gill, mantle, digestive gland, hematocyte, heart, visceral ganglia, and adductor muscle were rapidly excised, frozen in liquid nitrogen, and then stored at $-80{ }^{\circ} \mathrm{C}$ until use. Total RNA extraction and cDNA synthesis were performed as described above. The cDNA from the all eight tissues at each sampling point was pooled into one sample with equal amount per tissue, and used for real-time PCR analysis according to the method described above. 


\subsection{Low temperature culture experiment}

Oyster umbo larvae with similar size $(2.5 \pm 0.3 \mathrm{~mm})$ were stocked into three $75 \mathrm{~L}$ cylindrical polyethylene vessels (larval density of $4 / \mathrm{mL}$ ) and reared at $5 \pm 1{ }^{\circ} \mathrm{C}, 15 \pm 1{ }^{\circ} \mathrm{C}$ and $25 \pm 1{ }^{\circ} \mathrm{C}$, respectively. Light was supplied by fluorescent lamps with 12:12 Light: Dark photoperiod. For each culture temperature, three random replicates were allocated, the survival and feeding situation of the larvae was monitored daily for 10-day culture, the shell height of 30 randomly collected larvae was measured, and the whole larvae were collected and deposited into RNAstore (CWBIO, China) until used for RNA expression analyses.

\section{Results}

\subsection{Identification of ILPR, IRS, IGFBP, and IGFALS in C. gigas}

One $I L P R$, one IRS, one IGFBP, and seven IGFALS genes were identified in C. gigas through extensive genome and transcriptome data mining. The gene names, sequence characteristics and accessions were provided in Table 1. Phylogenetic analysis showed that the C. gigas ILPR was clustered into one clade with the ILPRs of arthropods and other mollusks, the vertebrates IGF1R, IGF2R, INSR, and INSRR were clustered into separate clades, respectively (Fig. 1). In addition, the IRS of $C$. gigas was clustered into one clade with the IRS of arthropods and other mollusks, while the three IRSs in vertebrates, IRS1, IRS2 and IRS4 were clustered into other separate clades, respectively (Supplementary Fig. 1). The only one IGFBPRP in C. gigas was clustered into the clade with vertebrate IGFBP7 (also known as IGFBPRP1) and IGFBPRP from other mollusks, while the other six vertebrate-specific IGFBP members were clustered into other separate clades, respectively (Supplementary Fig. 2). 
In striking contrast to the identification of only one IGFBP, seven IGFALSs were found in $C$. gigas. Phylogenetic analysis showed that the $C$. gigas ALS4336 was clustered into one clade with ALSs of Mizuhopecten yessoensis, the ALS7489 and ALS5594 in C. gigas were clustered into one clade with ALSs from the Crassostrea virginica, Mizuhopecten yessoensis, and Octopus bimaculoid, then the three ALSs in C. gigas were clustered into a larger clade with the ALSs from several vertebrates. Furthermore, the ALS1089, ALS2466, ALS7789 and ALS6223 in C. gigas were clustered into one clade with the ALS of Crassostrea virginica and had relatively closer homology to the ALS in invertebrates. The phylogenetic analysis also indicated that the ALS1089, ALS2466, ALS7789 and ALS6223 in C. gigas had a relatively primitive evolution status in comparison with other three ALSs, including the ALS4336, ALS7489 and ALS5594 (Supplementary Fig. 3).

3.2 Expression profiles of IIS, PIBK-AKT and RAS-MAPK signaling pathway genes between "Haida No.1" and wild oysters

The IIS signaling pathway genes including ILPR, IGFBPRP and IRS were all expressed at higher levels in fast-growing "Haida No. 1" than wild oysters (Fig. 2A). Among the seven $A L S$ genes, the $A L S 7789$ and $A L S 7489$ were highly expressed in "Haida No.1", while $A L S 5594$ was expressed at a higher level in wild oysters, and the other $A L S$ s showed no expression difference between "Haida No.1" and wild oysters (Fig. 2B).

The genes involved in PI3K-AKT and RAS-MAPK signaling pathways, including PI3K, $P D K, A K T, R A S, M E K$, and $E R K$, were all highly expressed in "Haida No.1" variety (Fig. 2C). Furthermore, downstream genes of the PI3K-AKT signaling pathway, including GSK3 $\beta$, FoxO, 
PTEN, TOR, and S6K, showed distinct expression profiles between the "Haida No.1" and wild oysters, with GSK3 $\beta$ and TOR being expressed at higher levels in "Haida No.1", while PTEN, FoxO and $S 6 K$ being expressed at higher levels in the wild oysters (Fig. 2D).

3.3 Effect of nutrient abundance on the IIS, PI3K-AKT and RAS-MAPK signaling pathway genes in C. gigas

Expression profiles of $I L P R, I R S$ and IGFBPRP genes were quite distinct in the fasting and re-feeding culture experiment. Specifically, ILPR, IRS and IGFBP were significantly down-regulated from day one to day 14 during the fasting treatment. Once refeeding, the expression of $I L P R$ was significantly up-regulated in one hour and peaked at $12 \mathrm{~h}$ and $24 \mathrm{~h}$, then decreased to a relative lower level at 36h (Fig. 3A), the expression of IRS was significantly upregulated at $3 \mathrm{~h}$ and peaked at $36 \mathrm{~h}$ (Fig. 3B), the expression of IGFBPRP was significantly upregulated in one hour and peaked at $3 \mathrm{~h}$, then decreased and maintained at a regular level comparable to that of control at 36h (Fig. 3C).

The expressions of the seven IGFALSs showed gene-specific expression patterns after fasting and re-feeding treatment. Both ALS5594, ALS7489, ALS2466 and ALS1089 genes were all significantly down-regulated from day one to day 14 during fasting treatment and upregulated in 1, 3 or 12 hours once re-feeding (Fig. 3D, E, F, G). In addition, the expression of $A L S 7789$ was firstly down-regulated from day one to day 3 , and then up-regulated from day 5 to day 14 during the fasting process. Once re-feeding, its expression was firstly down-regulated, then up-regulated during 1 to 3 hours, and finally maintained at a control level (Fig. $3 \mathrm{H})$. The expression of $A L S 4366$ was significantly up-regulated on day 3 and peaked on day 5, then 
decreased from day 7 to day 14 during the fasting process. Once refeeding, expression of ALS4366 was up-regulated at $3 \mathrm{~h}$ and peaked at 36h (Fig. 3I). The expression of ALS6223 was not affected by fasting and re-feeding treatment (Fig. 3J).

The expression profiles of TOR, S6K, FoxO and GSK3 3 genes were quite distinct after the fasting and re-feeding treatment. The TOR, $S 6 K$ and GSK3 $\beta$ showed stepwise decrease from day one to day 14 during fasting. Once refeeding, those genes were significantly up-regulated in one hour and peaked at 36h (Fig. 4A, B, C), the expression of FoxO was up-regulated continuously from day 1 to day 14 during fasting, then down-regulated from $3 \mathrm{~h}$ to $36 \mathrm{~h}$ to the control level once re-feeding (Fig. 4D).

3.4 Effect of temperature on the IIS, PI3K-AKT and RAS-MAPK signaling pathway genes in C. gigas

Low temperature significantly suppressed the growth of oyster larvae as well as the expression of the four insulin-like peptide genes [40]. Similarly, we found that the expression of the major IIS, PI3K-AKT and RAS-MAPK signaling pathway genes, including ILPR, IRS, IGFBPRP, ALS7789, ALS7489, ALS1089, PI3K, PDK, AKT, RAS, MEK, ERK, PTEN, TOR, GSK $3 \beta$ and $S 6 K$ genes were also suppressed under the low culture temperature (Fig. 5A, B, C). In contrast, expression levels of ALS5594, ALS2466, ALS6223 and ALS4336 genes were not affected (Fig. 5B), while the FoxO was expressed at a relatively higher level under low temperature than normal temperature (Fig. 5D).

\section{Discussion}


The involvement of insulin/insulin-like growth factor (IIS) signaling pathway in regulating growth and energy metabolism has been well-studied in vertebrates, while the role of IIS pathway in growth regulation of marine invertebrates such as oysters remains largely unexplored. In a previous study, we identified four insulin-like peptide genes in C. gigas, and showed that their expression levels were greatly associated with growth. While how the insulinlike peptides function to play roles in growth regulation of $C$. gigas deserves further investigation. In the present study, we performed an extensive bioinformatics data mining and identified one $I L P R$, one IRS, one IGFBP, and seven IGFALSs genes in C. gigas. Phylogenetic analysis confirmed their identities and reconstructed their evolutionary relationships, respectively. Expression profiling of the major genes of IIS and ILPR-mediated signaling pathways, including PI3K-AKT and RAS-MAPK signaling pathways, were all expressed at higher levels in the fast-growing "Haida No.1" oysters. Furthermore, expression levels of IIS, PI3K-AKT, RAS-MAPK and TOR signaling pathway genes were significantly affected by nutrient abundance and temperature in a gene-specific manner. These results suggested the critical roles of IIS signaling pathway in growth regulation of $C$. gigas, and confirmed the conserved role of the IIS and ILPR-mediated signaling pathways in growth control among various organisms.

Identification of IIS, PI3K-AKT, and RAS-MAPK signaling pathway genes in C. gigas suggested the conserved role of the IIS in growth and metabolism regulation. Phylogenetic analysis showed that the only one C. gigas ILPR was clustered with the ILPRs from other invertebrates and had a relatively closer homology with the insulin receptor (INSR) in comparison with other members of the IR subfamily in vertebrates, including the IGF1R, 
IGF2R and INSRR, indicating the similar physiological function between the ILPR in C. gigas and the insulin receptor in vertebrates. Notably, although four insulin-like peptide genes were found in $C$. gigas, there is only one ILPR, which was strikingly different from the case in vertebrates, deserving further investigations on the evolution of ligand and receptor binding for insulin-like peptides. The IRS, which could bind to the phosphorylated tyrosine residues of beta subunits of the ILPR, is involved in transducing the IIS signaling pathway within the cell $[42,43]$. In our present study, different from the vertebrates which have three IRS, only one IRS was identified in $C$. gigas, indicating specific binding of IRS to beta subunits of ILPR in C. gigas.

The IGFBP family is composed of six distinct types of IGFBP (IGFBP1-6) and ten IGFBPRP in vertebrates, which is evolutionarily ancient and conserved [9]. In invertebrates, there is no definite evidence indicating the existence of traditional IGFBP1-6 which could bind to IGF-I and IGF-II with higher affinity than the related proteins (IGFBPRP1 to IGFBPRP10) [44]. The IGFBP7, also known as IGFBPRP1, is distinct from other low-affinity IGFBPRP in that it can strongly bind to insulin [23], suggesting that IGFBP7 is likely to have special biological functions from other IGFBPs. In our present study, one IGFBPRP and seven ALSs were found in C. gigas, and the IGFBPRP was clustered into one clade with the IGFBPRP from other mollusks and IGFBP7 from vertebrates. Our analysis suggested that the C. gigas IGFBPRP had a similar evolutionary origin and physiological function with the IGFBP7 in vertebrates, supporting that the IGFBPRP (IGFBP7) may be the most ancient gene member among the IGFBP subfamily. Furthermore, the number of ALS is only one or two in vertebrates, while there are usually five to seven IGFALSs in arthropods and mollusks. The obviously larger 
number of IGFALSs in invertebrates than in vertebrates indicated that some of the ALSs could have been lost during the evolution after divergence of invertebrates and vertebrates.

Higher expression levels of insulin-like peptide genes were associated with fast-growth in the $C$. gigas as revealed in our previous study. In the present work, expression profiles of the major genes in the IIS signaling pathway were further determined to confirm the systemic regulatory role of IIS signaling pathway in growth regulation of oysters. Our results showed that the major genes of the IIS signaling pathway, including ILPR, IRS and IGFBPRP were all expressed higher in the fast-growing "Haida No.1" than wild oysters. However, the C. gigas ALSs showed distinct expression profiles. The ALS has been reported to play an indispensable role in growth regulation of vertebrates $[45,46]$. In our present study, the $A L S 5594$ gene was expressed higher in wild oysters, while the $A L S 7789$ and $A L S 7489$ genes were expressed at higher levels in the "Haida No.1" oysters, indicating that the ALS also played important but diverse roles in growth regulation of $C$. gigas.

In vertebrates, once the ternary complex "IGFs/insulins-IGFBP-ALS" binds to the receptor, the receptor is auto-phosphorylated and recruits the IRS, then the IRS would trigger different downstream signaling pathways such as the PI3K-AKT and RAS-MAPK signaling pathways [47-49]. The MAPK and its downstream response elements are involved in cell growth and proliferation [50]. The activation of PI3K led to production of PIP3, which in turn promoted the activation of downstream factors such as AKT, TOR and GSK $3 \beta$ to regulate cell proliferation, energy metabolism and hormone secretion $[51,52]$. In our present study, we found that the ILPR mediated signaling pathway was conserved among vertebrates and invertebrates. The major genes of PI3K-AKT and RAS-MAPK signaling pathways, including 
the $P I 3 K, P D K, A K T, R A S, M E K, E R K, T O R$, and $G S K 3 \beta$ were all expressed at higher levels in "Haida No.1" variety, while the negative regulators PTEN, FoxO and S6K were all highly expressed in wild oysters. Therefore, ILPR is speculated to transduce signaling from the active ternary complex "ILP-IGFBP-ALS" to the downstream PI3K-AKT and RAS-MAPK signaling pathways, functioning to regulate energy metabolism and cell proliferation in oysters (Fig. 6).

Fasting/re-feeding and low temperature culture experiments were performed to further confirm the speculation. In our present study, the major genes of IIS signaling pathway including the ILPR, IRS, IGFBP, and the seven $A L S s$ all showed different expression patterns during fasting and re-feeding process. The expressions of ILPR, IRS, IGFBP, ALS5594, ALS7489, ALS2466 and ALS1089 genes all decreased once food was deprived and recovered to normal level once re-feeding, which were consistent with the expression profile of insulinlike peptide (ILP) gene in our previous study [40]. These results suggested that ILP, ILPR, IRS, IGFBP and ALSs may play systemic roles in food intake, nutrient digestion and absorption through the ternary complex "ILP-IGFBPRP-ALS" in C. gigas. In addition, the expressions of $A L S 7789$ and $A L S 4336$ genes were all up-regulated during fasting and re-feeding process, which were consistent with the expression profiles of MIRP3, MIRP3-like and ILP7 genes in our previous study [40]. We speculate that the ALS7789 and ALS4336 may be associated with physiological role of molluscan insulin-related peptide 3 (MIRP3), molluscan insulin-related peptide 3-like (MIRP3-like) and insulin-like peptide 7 (ILP7), and are indispensable in energy metabolism under the control of neuroendocrine activity. Furthermore, low temperature greatly suppressed the expressions of ILPR, IRS, IGFBP, ALS7789, ALS7489, and ALS1089 genes. These results suggested that the IIS signaling pathway is responsive to fluctuations of nutrition 
condition and ambient temperature.

The key elements of the PI3K-AKT and RAS-MAPK also showed different expression patterns during fasting and re-feeding process. The TOR nutrient pathway, which is regulated by insulin, nutrient abundance, energy and growth factors, function to modulate insulinstimulated glucose transport, cellular metabolism, growth and proliferation [2]. In addition, the TORC1 activate the translational regulator S6K (S6 kinase), leading to increase protein synthesis in the presence of nutrients [53-56]. In our study, the expressions of TOR and S6K genes were all decreased during fasting and recovered to normal level once refeeding. GSK3 $\beta$ phosphorylates serine and threonine sites of a variety of substrates, including glycogen synthase, to regulate glycogen synthesis [58]. In our previous study, the expression of GSK3 $\beta$ was inhibited under food deprivation condition and recovered to normal level once the food was abundant, indicting the reduction of glycogen synthesis under food deprivation condition. As the negative regulator, FoxO regulates cell proliferation and energy metabolism through the transcriptional activation of certain genes [58]. In our study, the expression of FoxO was upregulated during fasting and down-regulated once re-feeding. Furthermore, the expressions of IIS and ILPR mediated signaling pathway genes were all inhibited under low culture temperature except for the negative regulator FoxO. These results confirm that the IIS and ILPR mediated signaling pathways are conserved and ILPR could transduce signaling from the active ternary complex "ILP-IGFBP-ALS" to the downstream PI3K-AKT and RAS-MAPK signaling, functioning to regulate the energy metabolism and cell proliferation of C. gigas (Fig. $6)$.

In summary, we identified and characterized one $I L P R$, one $I R S$, one $I G F B P R P$, and seven 
IGFALSs in C. gigas. Expression profiling of these genes between fast-growing oysters and slow-growing wild oysters suggested their critical roles in growth regulation. The nutrient abundance and ambient temperature greatly affected the expression profiles of these genes. Furthermore, major genes of the ILPR-mediated PI3K-AKT and RAS-MAPK signaling pathways were all expressed at higher levels in the fast-growing "Haida No.1" variety, and were significantly suppressed under low temperature condition. These observations suggest that the IIS signaling pathway is involved in the growth regulation of $C$. gigas through regulating food intake, nutrition metabolism and cell proliferation. This work provid valuable information for further investigation on growth regulation mechanism in mollusks as well as other invertebrates.

\section{Acknowledgments}

This work was supported by the grants from National Natural Science Foundation of China (Nos. 31802293, 41976098 and 31741122), the Young Talent Program of Ocean University of China (No. 201812013), Laboratory for Marine Fisheries Science and Food Production Processes, Qingdao National Laboratory for Marine Science and Technology (No. 2017-2A04), and China Postdoctoral Science Foundation (No. 2017M622283).

\section{Author contributions}

SL conceived and designed the study. YL, HF, FZ, LR, and JT collected the samples and executed the experiments. YL, HF and SL analyzed the data. YL drafted the manuscript, and SL revised the manuscript. QL provided reagents and materials and supervised the study. All 
bioRxiv preprint doi: https://doi.org/10.1101/2021.02.25.432956; this version posted February 27, 2021. The copyright holder for this preprint (which was not certified by peer review) is the author/funder, who has granted bioRxiv a license to display the preprint in perpetuity. It is made available under aCC-BY-NC-ND 4.0 International license.

authors have read and approved the final version of the manuscript.

\section{Availability of data and materials}

All data generated and analyzed during this study are included in this published article and its supplementary files.

\section{Competing interests}

The authors declare that there are no financial or other potential conflicts of interests. 


\section{References}

[1] N.M. Templeman, C.T. Murphy, Regulation of reproduction and longevity by nutrientsensing pathways, J Cell Biol, 217 (2018) 93-106.

[2] G.Y. Liu, D.M. Sabatini, mTOR at the nexus of nutrition, growth, ageing and disease, Nat Rev Mol Cell Biol, 21 (2020) 183-203.

[3] L. Plum, B.F. Belgardt, J.C. Brüning, Central insulin action in energy and glucose homeostasis, J Clin Invest, 116 (2006) 1761-1766.

[4] C. Duan, H. Ren, S. Gao, Insulin-like growth factors (IGFs), IGF receptors, and IGFbinding proteins: Roles in skeletal muscle growth and differentiation, Gen Comp Endocrinol, 167 (2010) 344-351.

[5] L. Laviola, A. Natalicchio, F. Giorgino, The IGF-I signaling pathway, Curr Pharm Des, 13 (2007) 663-669.

[6] Z. Fu, E.R. Gilbert, D. Liu, Regulation of insulin synthesis and secretion and pancreatic beta-cell dysfunction in diabetes, Curr Diabetes Rev, 9 (2013) 25-53.

[7] V.E. Bianchi, V. Locatelli, L. Rizzi, Neurotrophic and neuroregenerative effects of GH/IGF1, Int J Mol Sci, 18 (2017) 2441-2466.

[8] B. Moore, A. Whitehead, K. Davies, Short stature, growth hormone deficiency, and primary IGF-1 deficiency, (2019). In: Llahana S., Follin C., Yedinak C., Grossman A. (eds) Advanced Practice in Endocrinology Nursing. Springer, Cham.

[9] J.B. Allard, C. Duan, IGF-Binding Proteins: Why do they exist and why are there so many?, Front Endocrinol (Lausanne), 9 (2018) 117-129.

[10] F. Hakuno, S.I. Takahashi, IGF1 receptor signaling pathways, J Mol Endocrinol, 61 (2018) t69-t86.

[11] H.R. Khan, B. Griffond, A.S. Saleuddin, Insulin-like peptide(s) in the central nervous system of the snail Helisoma duryi, Brain Res, 580 (1992) 111-114.

[12] D.R. Nässel, J. Vanden Broeck, Insulin/IGF signaling in Drosophila and other insects: factors that regulate production, release and post-release action of the insulin-like peptides, Cell Mol Life Sci, 73 (2016) 271-290.

[13] S. Satake, M. Masumura, H. Ishizaki, K. Nagata, H. Kataoka, A. Suzuki, A. Mizoguchi, 
Bombyxin, an insulin-related peptide of insects, reduces the major storage carbohydrates in the silkworm Bombyx mori, Comp Biochem Physiol B Biochem Mol Biol, 118 (1997) 349-357. [14] W.P. Geraerts, Control of growth by the neurosecretory hormone of the light green cells in the freshwater snail Lymnaea stagnalis, Gen Comp Endocrinol, 29 (1976) 61-71.

[15] A. Gomot, L. Gomot, C.R. Marchand, C. Colard, J. Bride, Immunocytochemical localization of insulin-related peptide(s) in the central-nervous-system of the snail helixaspersa muller - involvement in growth-control, Cell Mol Neurobiol, 12 (1992) 21-32.

[16] M. Gorczyca, C. Augart, V. Budnik, Insulin-like receptor and insulin-like peptide are localized at neuromuscular junctions in Drosophila, J Neurosci, 13 (1993) 3692-3704.

[17] L.P. Schot, H.H. Boer, D.F. Swaab, S. Van Noorden, Immunocytochemical demonstration of peptidergic neurons in the central nervous system of the pond snail Lymnaea stagnalis with antisera raised to biologically active peptides of vertebrates, Cell Tissue Res, 216 (1981) 273 291.

[18] A.B. Smit, E. Vreugdenhil, R.H. Ebberink, W.P. Geraerts, J. Klootwijk, J. Joosse, Growthcontrolling molluscan neurons produce the precursor of an insulin-related peptide, Nature, 331 (1988) 535-538.

[19] W. Brogiolo, H. Stocker, T. Ikeya, F. Rintelen, R. Fernandez, E. Hafen, An evolutionarily conserved function of the Drosophila insulin receptor and insulin-like peptides in growth control, Curr Biol, 11 (2001) 213-221.

[20] Y. Shi, Y. Guan, M. He, Molecular identification of insulin-related peptide receptor and its potential role in regulating development in Pinctada fucata, Aquaculture, 408-409 (2013) 118127.

[21] D.R. Nässel, Y. Liu, J. Luo, Insulin/IGF signaling and its regulation in Drosophila, Gen Comp Endocrinol, 221 (2015) 255-266.

[22] B. Honegger, M. Galic, K. Köhler, F. Wittwer, W. Brogiolo, E. Hafen, H. Stocker, ImpL2, a putative homolog of vertebrate IGF-binding protein 7, counteracts insulin signaling in Drosophila and is essential for starvation resistance, J Biol, 7 (2008) 10-21.

[23] N. Li, Z. Zhang, L. Zhang, S. Wang, Z. Zou, G. Wang, Y. Wang, Insulin-like growth factor binding protein 7, a member of insulin-like growth factor signal pathway, involved in immune response of small abalone Haliotis diversicolor, Fish Shellfish Immunol, 33 (2012) 229-242. 
[24] L. Feng, X. Li, Q. Yu, X. Ning, J. Dou, J. Zou, L. Zhang, S. Wang, X. Hu, Z. Bao, A scallop IGF binding protein gene: molecular characterization and association of variants with growth traits, PLoS One, 9 (2014) e89039.

[25] O. Rosen, S. Weil, R. Manor, Z. Roth, I. Khalaila, A. Sagi, A crayfish insulin-like-binding protein: another piece in the androgenic gland insulin-like hormone puzzle is revealed, J Biol Chem, 288 (2013) 22289-22298.

[26] J.C. Chandler, J. Aizen, A. Elizur, L. Hollander-Cohen, S.C. Battaglene, T. Ventura, Discovery of a novel insulin-like peptide and insulin binding proteins in the Eastern rock lobster Sagmariasus verreauxi, Gen Comp Endocrinol, 215 (2015) 76-87.

[27] F. Li, H. Bai, Y. Xiong, H. Fu, S. Jiang, F. Jiang, S. Jin, S. Sun, H. Qiao, W. Zhang, Molecular characterization of insulin-like androgenic gland hormone-binding protein gene from the oriental river prawn Macrobrachium nipponense and investigation of its transcriptional relationship with the insulin-like androgenic gland hormone gene, Gen Comp Endocrinol, 216 (2015) 152-160.

[28] A. Jouaux, A. Franco, C. Heude-Berthelin, P. Sourdaine, J.L. Blin, M. Mathieu, K. Kellner, Identification of Ras, Pten and p70S6K homologs in the Pacific oyster Crassostrea gigas and diet control of insulin pathway, Gen Comp Endocrinol, 176 (2012) 28-38.

[29] I. Claeys, G. Simonet, J. Poels, T. Van Loy, L. Vercammen, A. De Loof, J. Vanden Broeck, Insulin-related peptides and their conserved signal transduction pathway, Peptides, 23 (2002) 807-816.

[30] C.T. Murphy, P.J. Hu, Insulin/insulin-like growth factor signaling in C. elegans, WormBook : the online review of C. elegans biology, (2013) 1-43.

[31] Y.H. Choi, E.-Y. Kim, T.J. Nam, Involvement of insulin-like growth factor in intraspecific variation in growth of Pacific oyster Crassostrea gigas during winter, Fisheries Science, 84 (2018) 1017-1024.

[32] E.Y. Kim, Y.H. Choi, Regulation of adductor muscle growth by the IGF-1/AKT pathway in the triploid Pacific oyster, Crassostrea gigas, Fisheries and Aquatic Sciences, 22 (2019) 22 (2019) 19-29.

[33] Y. Shi, M.X. He, PfIRR Interacts with HrIGF-I and activates the MAP-kinase and PI3kinase signaling pathways to regulate glycogen metabolism in Pinctada fucata, Sci Rep, 6 
(2016) 22063-22076.

[34] Y. Umezaki, S.E. Hayley, M.L. Chu, H.W. Seo, P. Shah, F.N. Hamada, Feeding-Statedependent modulation of temperature preference requires insulin signaling in drosophila warmsensing neurons, Curr Biol, 28 (2018) 779-787.

[35] S. Hyun, Body size regulation and insulin-like growth factor signaling, Cell Mol Life Sci, 70 (2013) 2351-2365.

[36] H. Zhang, M. He, The role of a new insulin-like peptide in the pearl oyster Pinctada fucata martensii, Sci Rep, 10 (2020) 433-460.

[37] K. Troost, Causes and effects of a highly successful marine invasion: Case-study of the introduced Pacific oyster Crassostrea gigas in continental NW European estuaries, Journal of Sea Research, 64 (2010) 145-165.

[38] F. Zhang, B. Hu, H. Fu, Z. Jiao, Q. Li, S. Liu, Comparative transcriptome analysis reveals molecular basis underlying fast growth of the selectively bred Pacific Oyster, Crassostrea gigas, Front Genet, 10 (2019) 610-624.

[39] J. Zhang, Q. Li, C. Xu, Z. Han, Response to selection for growth in three selected strains of the Pacific oyster Crassostrea gigas, Aquaculture, 503 (2019) 34-39.

[40] Y. Li, H. Fu, F. Zhang, L. Ren, J. Tian, Q. Li, S. Liu, Identification, characterization, and expression profiles of insulin-like peptides suggest their critical roles in growth regulation of the Pacific oyster, Crassostrea gigas, Gene, 769 (2021) 145244.

[41] S. Kumar, G. Stecher, K. Tamura, MEGA7: Molecular Evolutionary Genetics Analysis Version 7.0 for Bigger Datasets, Mol Biol Evol, (2016) 1870-1874.

[42] R.A. Haeusler, T.E. McGraw, D. Accili, Biochemical and cellular properties of insulin receptor signalling, Nat Rev Mol Cell Biol, 19 (2018) 31-44.

[43] S. Payankaulam, A.M. Raicu, D.N. Arnosti, Transcriptional regulation of INSR, the insulin receptor gene, Genes, 10 (2019) 984-1006.

[44] X. Huang, H. Ye, B. Feng, H. Huang, Insights into insulin-like peptide system in invertebrates from studies on IGF binding domain-containing proteins in the female mud crab, Scylla paramamosain, Mol Cell Endocrinol, 416 (2015) 36-45.

[45] S. Yakar, C.J. Rosen, M.L. Bouxsein, H. Sun, W. Mejia, Y. Kawashima, Y. Wu, K. Emerton, V. Williams, K. Jepsen, M.B. Schaffler, R.J. Majeska, O. Gavrilova, M. Gutierrez, D. Hwang, 
P. Pennisi, J. Frystyk, Y. Boisclair, J. Pintar, H. Jasper, H. Domene, P. Cohen, D. Clemmons, D. LeRoith, Serum complexes of insulin-like growth factor-1 modulate skeletal integrity and carbohydrate metabolism, FASEB J, 23 (2009) 709-719.

[46] Y.R. Boisclair, K.R. Hurst, I. Ueki, M.L. Tremblay, G.T. Ooi, Regulation and role of the acid-labile subunit of the 150-kilodalton insulin-like growth factor complex in the mouse, Pediatr Nephrol, 14 (2000) 562-566.

[47] J. Zha, M.R. Lackner, Targeting the insulin-like growth factor receptor-1R pathway for cancer therapy, Clin Cancer Res, 16 (2010) 2512-2517.

[48] M.F. White, The IRS-signalling system: A network of docking proteins that mediate insulin action, Mol Cell Biochem, 182 (1998) 3-11.

[49] J.P. Whitehead, S.F. Clark, B. Ursø, D.E. James, Signalling through the insulin receptor, Curr Opin Cell Biol, 12 (2000) 222-228.

[50] J. Blenis, . Signal transduction via the MAP kinases: proceed at your own RSK, Proc Natl Acad Sci U S A, 90 (1993) 5889-5892.

[51] D.R. Alessi, P. Cohen, Mechanism of activation and function of protein kinase B, Curr Opin Genet Dev, 148 (1998) 55-62.

[52] P.R. Shepherd, D.J. Withers, K. Siddle, Phosphoinositide 3-kinase: the key switch mechanism in insulin signalling, Biochem J, 333 ( Pt 3) (1998) 471-490.

[53] M.A. Destefano, E. Jacinto, Regulation of insulin receptor substrate-1 by mTORC2 (mammalian target of rapamycin complex 2), Biochem Soc Trans, 41 (2013) 809-901.

[54] R.E. Rhoads, Signal transduction pathways that regulate eukaryotic protein synthesis, J Biol Chem, 274 (1999) 30337-30340.

[55] V.H. Emilie, L. Seong-Il, B. Sricharan, T.J. Griffin, K. Do-Hyung, Insulin signalling to mTOR mediated by the Akt/PKB substrate PRAS40, Nat Cell Biol, 9 (2007) 316-323.

[56] F. Tremblay, A. Marette, Amino acid and insulin signaling via the mTOR/p70 S6 kinase pathway. A negative feedback mechanism leading to insulin resistance in skeletal muscle cells, J Biol Chem, 276 (2001) 38052-38060.

[57] M. Bouskila, M.F. Hirshman, J. Jensen, L.J. Goodyear, K. Sakamoto, Insulin promotes glycogen synthesis in the absence of GSK3 phosphorylation in skeletal muscle, Am J Physiol Endocrinol Metab, 294 (2008) E28-E35. 
bioRxiv preprint doi: https://doi.org/10.1101/2021.02.25.432956; this version posted February 27, 2021. The copyright holder for this preprint (which was not certified by peer review) is the author/funder, who has granted bioRxiv a license to display the preprint in perpetuity. It is made available under aCC-BY-NC-ND 4.0 International license.

[58] C.C. Chen, S.M. Jeon, P.T. Bhaskar, V. Nogueira, D. Sundararajan, I. Tonic, Y. Park, N. Hay, FoxOs inhibit mTORC1 and activate Akt by inducing the expression of Sestrin3 and Rictor, Dev Cell, 18 (2010) 592-604. 


\section{Tables}

Table 1. Sequence characteristics of the IIS signaling pathway genes in Crassostrea gigas

\begin{tabular}{|c|c|c|c|c|c|}
\hline Gene name & Gene full name & $\begin{array}{l}\text { Amino } \\
\text { acid (aa) }\end{array}$ & mRNA (bp) & ORF (bp) & $\begin{array}{l}\text { NCBI Gene } \\
\text { ID }\end{array}$ \\
\hline$I L P R$ & $\begin{array}{l}\text { Insulin-like peptide } \\
\text { receptor }\end{array}$ & 1561 & 9092 & 4686 & 105348544 \\
\hline$I R S$ & $\begin{array}{l}\text { Insulin receptor substrate } \\
1-B\end{array}$ & 1400 & 6375 & 4203 & 105342662 \\
\hline$I G F B P R P$ & $\begin{array}{l}\text { Insulin-like growth } \\
\text { factor-binding protein- } \\
\text { related protein } 1\end{array}$ & 258 & 1926 & 777 & 105339347 \\
\hline ALS5594 & $\begin{array}{l}\text { Insulin-like growth } \\
\text { factor-binding protein } \\
\text { complex acid labile } \\
\text { subunit }\end{array}$ & 978 & 4175 & 2937 & 105319673 \\
\hline$A L S 7789$ & $\begin{array}{l}\text { Insulin-like growth } \\
\text { factor-binding protein } \\
\text { complex acid labile } \\
\text { subunit }\end{array}$ & 780 & 2607 & 2343 & 105342519 \\
\hline$A L S 7489$ & $\begin{array}{l}\text { Insulin-like growth } \\
\text { factor-binding protein } \\
\text { complex acid labile } \\
\text { subunit }\end{array}$ & 1000 & 3987 & 3003 & 105342288 \\
\hline$A L S 2466$ & $\begin{array}{l}\text { Insulin-like growth } \\
\text { factor-binding protein } \\
\text { complex acid labile } \\
\text { subunit }\end{array}$ & 913 & 4713 & 2744 & 105338877 \\
\hline ALS6223 & $\begin{array}{l}\text { Insulin-like growth } \\
\text { factor-binding protein } \\
\text { complex acid labile } \\
\text { subunit }\end{array}$ & 349 & 1726 & 1050 & 105320119 \\
\hline ALS1089 & $\begin{array}{l}\text { Insulin-like growth } \\
\text { factor-binding protein } \\
\text { complex acid labile } \\
\text { subunit }\end{array}$ & 456 & 4620 & 1371 & 105324304 \\
\hline ALS4336 & $\begin{array}{l}\text { Insulin-like growth } \\
\text { factor-binding protein } \\
\text { complex acid labile } \\
\text { subunit }\end{array}$ & 858 & 3189 & 2577 & 105331921 \\
\hline
\end{tabular}




\section{Figure legends}

Fig. 1. Phylogenetic analyses of the insulin receptors and insulin-like peptide receptors. The amino acid sequences of insulin receptors and insulin-like peptide receptors from Homo sapiens, Gallus gallus, Xenopus laevis, Anolis carolinensis, Danio rerio, Limulus polyphemus, Musca domestica, Ctenocephalides felis, Mizuhopecten yessoensis, Tetranychus urticae, Octopus bimaculoid, Pomacea canaliculata, Crassostrea virginica and Crassostrea gigas were retrieved from the NCBI database. Phylogenetic tree was constructed using neighbor-joining (NJ) approach in MEGA7. The reliability of topological structure was tested using 1000 bootstrap replications.

Fig. 2. Expression profiles of the IIS, PI3K-AKT, RAS-MAPK, and TOR signaling pathway genes. Data are expressed as the mean \pm SD $(n=4)$. The significant difference $(P<0.05)$ among groups is indicated by the asterisk.

Fig. 3. Effects of fasting and re-feeding on expressions of the IIS signaling pathway genes. C represented the control group, F1d, F3d, F5d, F7d and F14d represented 1, 3, 5, 7 and 14 days after fasting, respectively; R1h, R3h, R6h, R12h, R24h and R36h represented 1, 3, 6, 12, 24 and 36 hours after re-feeding, respectively. Data are expressed as the mean $\pm \operatorname{SD}(n=3)$. The significant difference $(P<0.05)$ among timepoints is indicated by the different lowercase letters.

Fig. 4. Effects of fasting and re-feeding on expressions of genes in the PI3K-AKT, RAS-MAPK, and TOR signaling pathways. C represented the control group, F1d, F3d, F5d, F7d and F14d represented 1, 3, 5, 7 and 14 days after fasting, respectively; R1h, R3h, R6h, R12h, R24h and 
R36h represented 1, 3, 6, 12, 24 and 36 hours after re-feeding, respectively. Data are expressed as the mean $\pm \mathrm{SD}(\mathrm{n}=3)$. The significant difference $(P<0.05)$ among timepoints is indicated by the different lowercase letters.

Fig. 5. Effects of low temperature on the expressions of the IIS, PI3K-AKT, RAS-MAPK, and TOR signaling pathway genes. Data are expressed as the mean $\pm \operatorname{SD}(n=3)$. The significant difference $(P<0.05)$ among groups is indicated by the different lowercase letters.

Fig. 6. The proposed model of ILPR mediated IIS signaling pathway in growth regulation of C. gigas. The binding of insulin-like peptide to its receptor (ILPR) induces conformational changes in the alpha and beta subunits of the receptor. The IRS binds to the activated sites of the beta subunits and transduces signal to the cell through the PI3K-AKT and RAS-MAPK signaling pathways. The other elements including PTEN, GSK3 $\beta$, FoxO, TOR could regulate the activation of the PI3K-AKT signaling pathway in $C$. gigas through a similar way as in vertebrates. The rapamycin-sensitive TORC1 (TOR complex 1) activates the translational regulator S6K (S6 kinase), leading to increased protein synthesis in the presence of nutrients, and the S6K could inhibit the activity of the IRS, finally regulate the PI3K-AKT and RASMAPK signaling pathways. 
Fig. 1

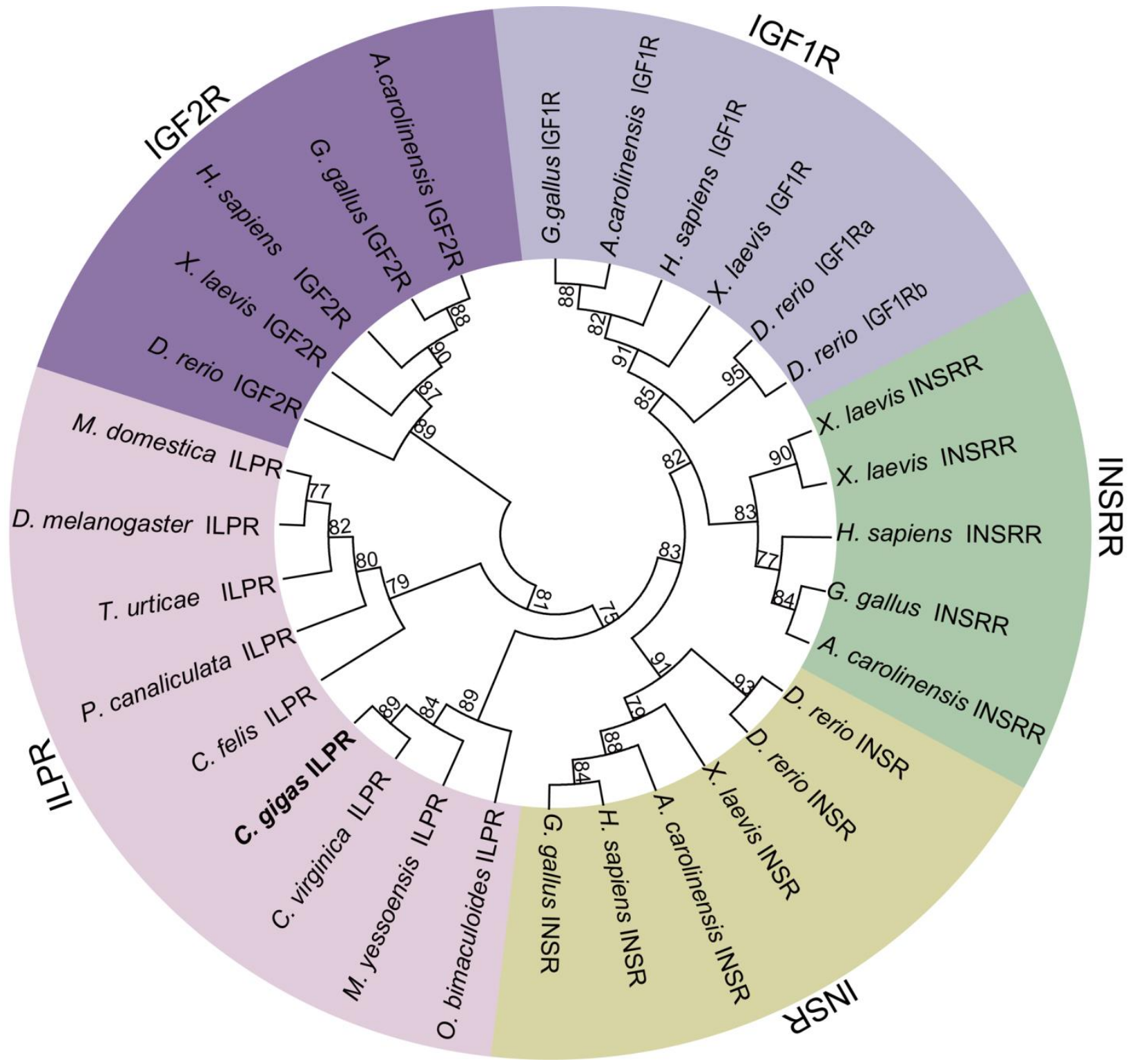


bioRxiv preprint doi: https://doi.org/10.1101/2021.02.25.432956; this version posted February 27, 2021. The copyright holder for this preprint (which was not certified by peer review) is the author/funder, who has granted bioRxiv a license to display the preprint in perpetuity. It is made available under aCC-BY-NC-ND 4.0 International license.

Fig. 2.
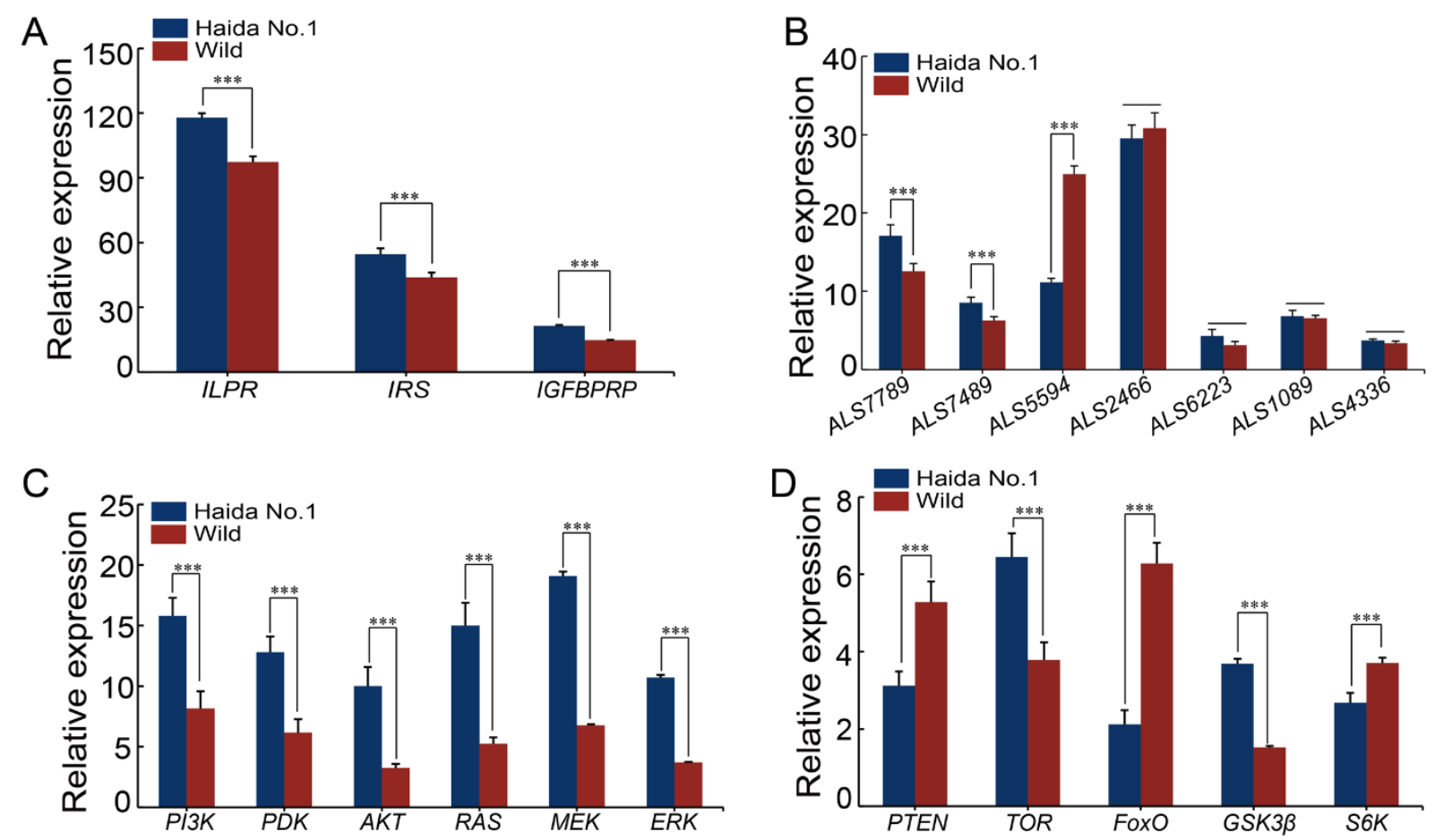
bioRxiv preprint doi: https://doi.org/10.1101/2021.02.25.432956; this version posted February 27, 2021. The copyright holder for this

Fig. 3

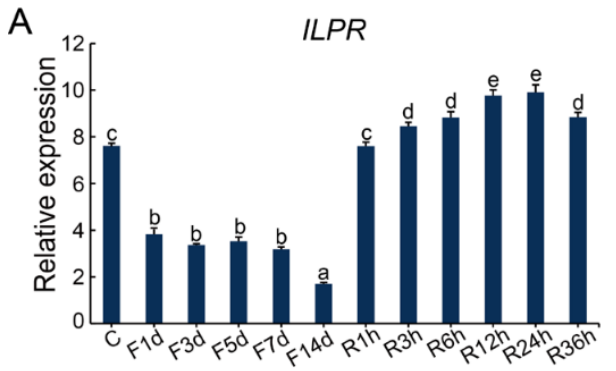

B

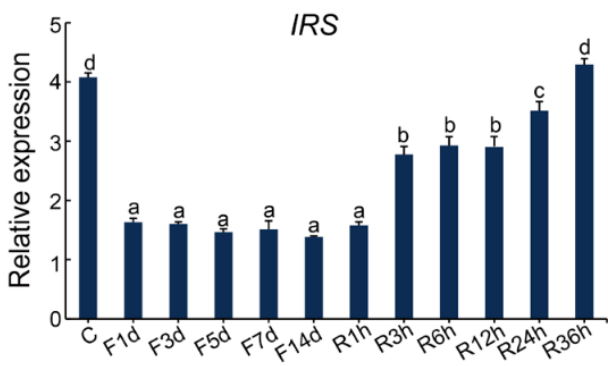

C

$\mathrm{E}$

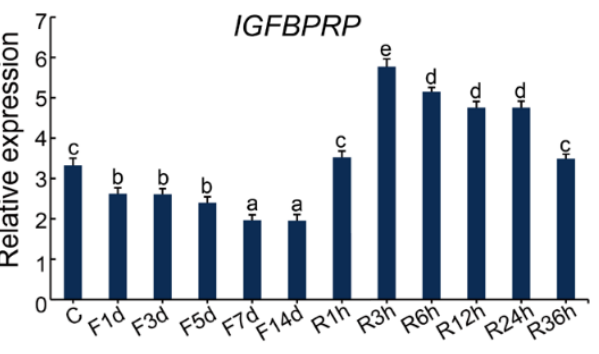

ALS7489

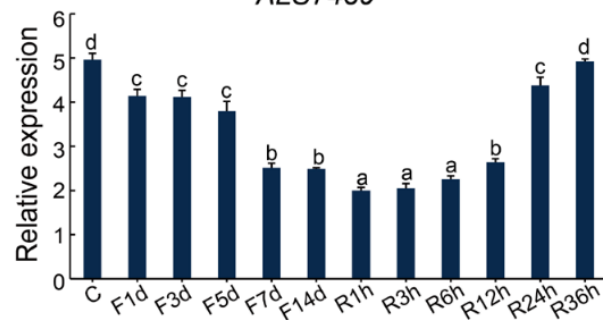

G
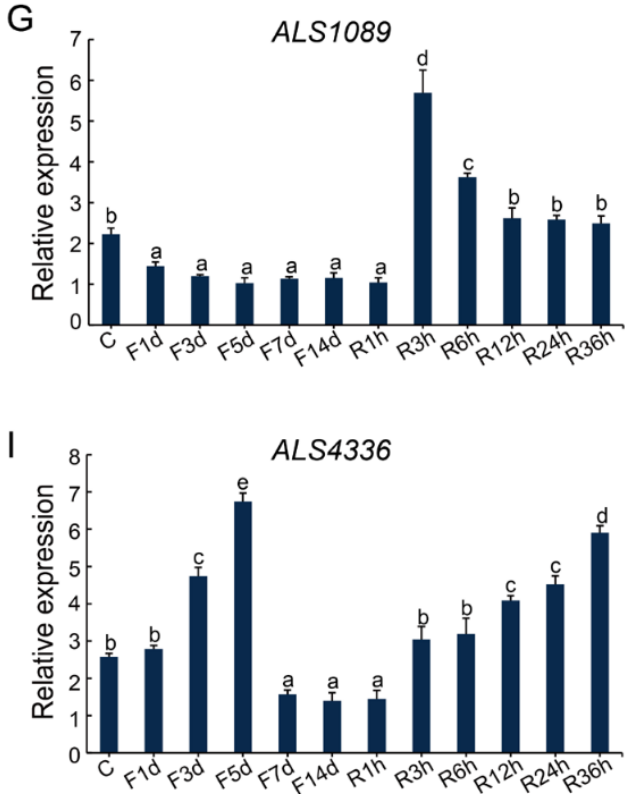

D
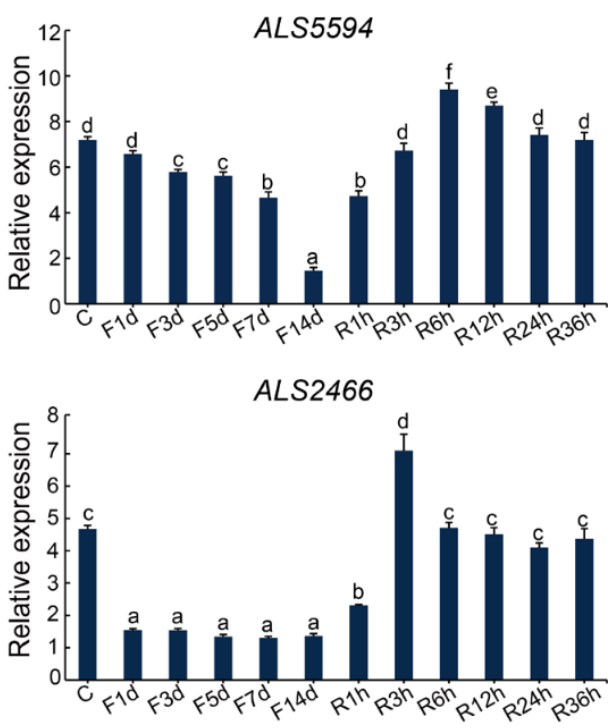

$\mathrm{H}$
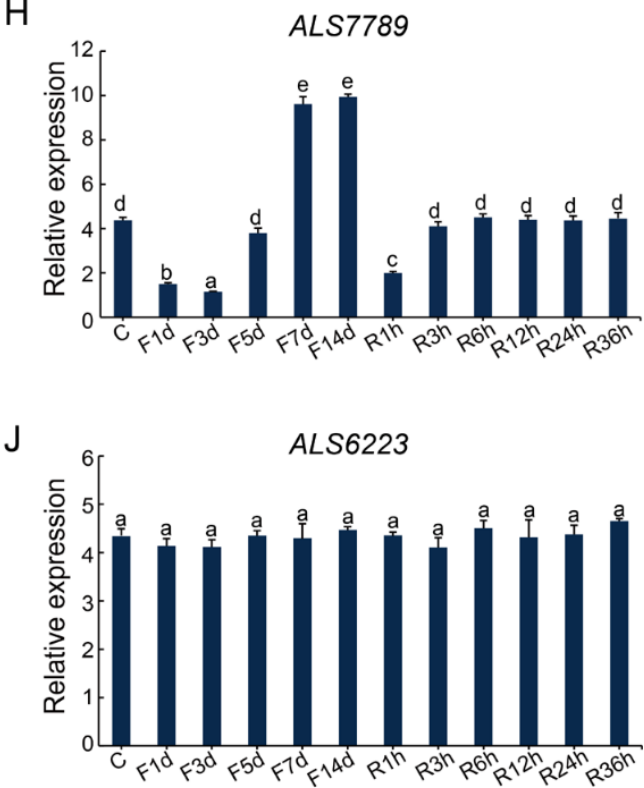
bioRxiv preprint doi: https://doi.org/10.1101/2021.02.25.432956; this version posted February 27, 2021. The copyright holder for this preprint (which was not certified by peer review) is the author/funder, who has granted bioRxiv a license to display the preprint in perpetuity. It is made available under aCC-BY-NC-ND 4.0 International license.

Fig. 4

A

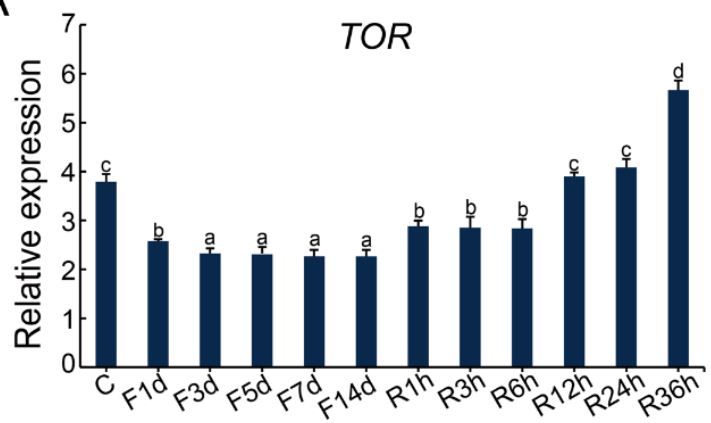

C

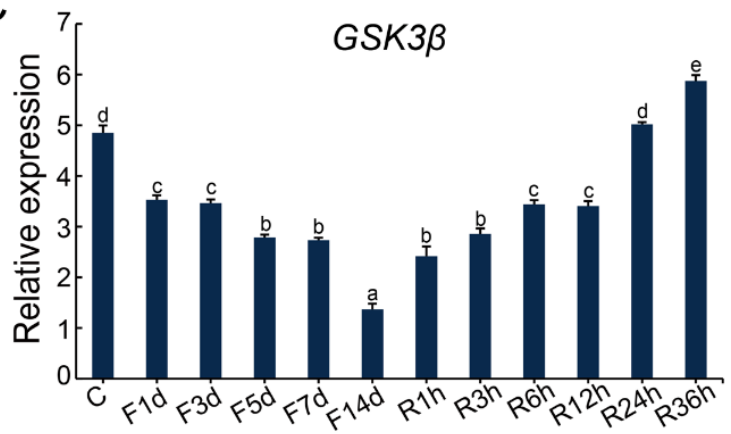

B

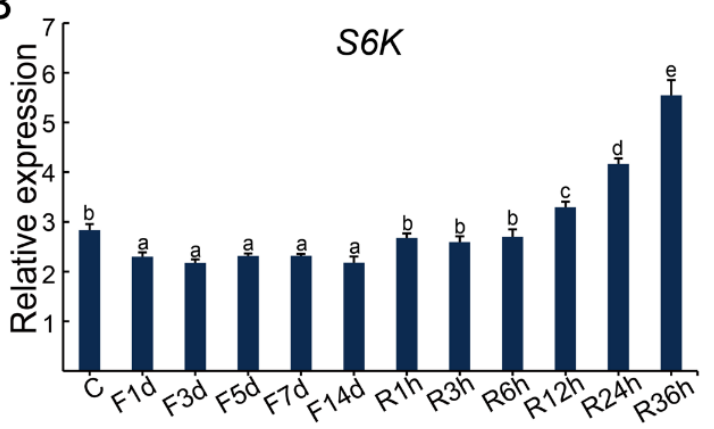

D

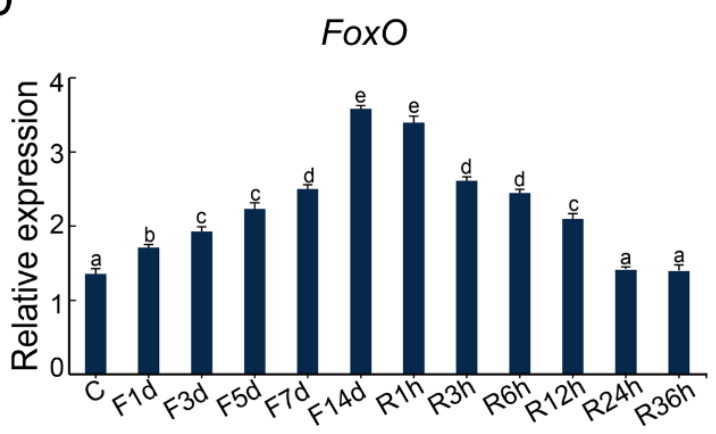


T. Wul.

Euth Hith 
bioRxiv preprint doi: https://doi org/10.1101/2021.02 25.432956 this version posted February 27, 2021. The copyright holder for this preprint (which was not certified by peer review) is the author/funder, who has granted bioRxiv a license to display the preprint in perpetuity. It is made available under aCC-BY-NC-ND 4.0 International license.

Fig. 6

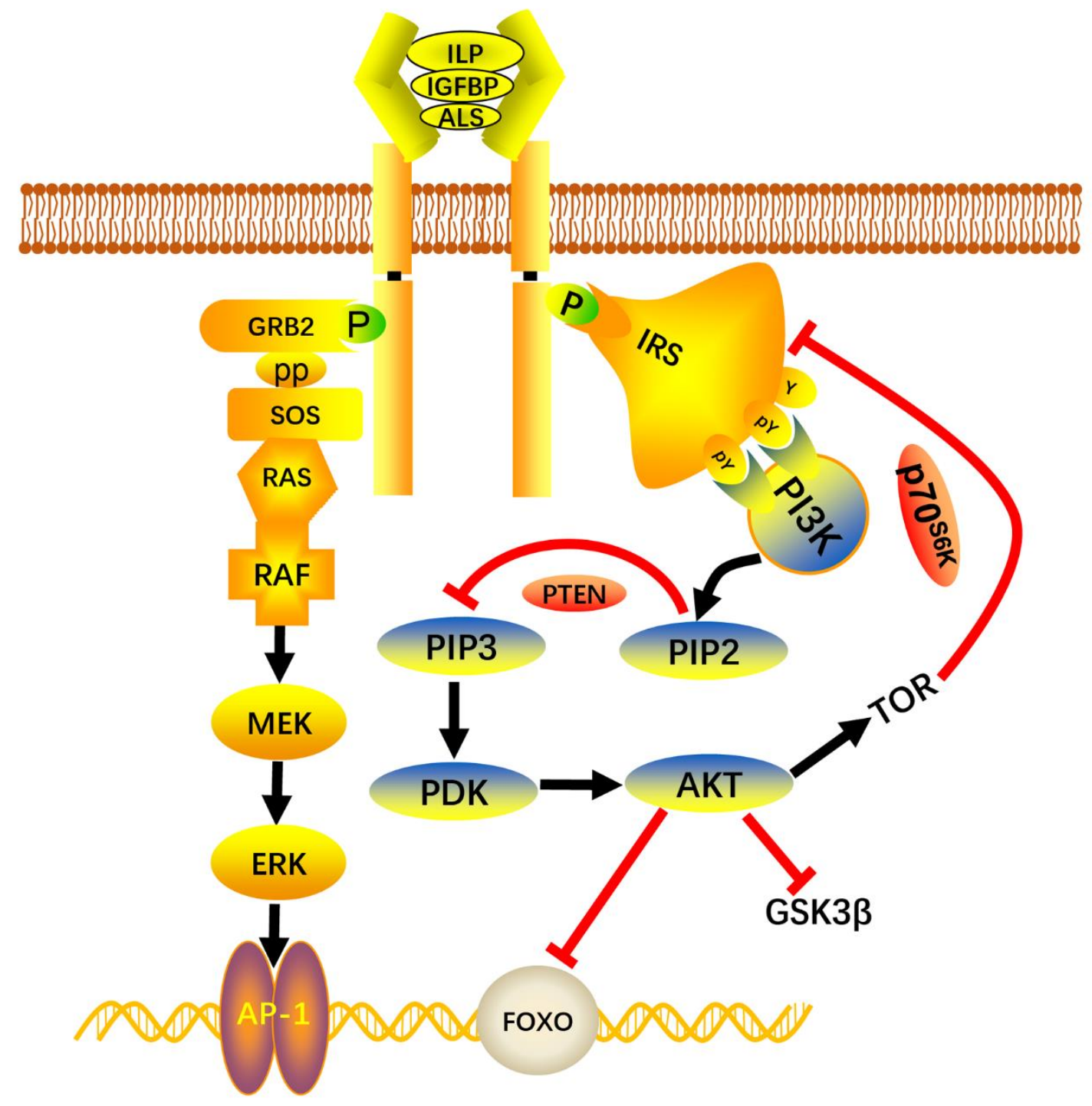

